\title{
Examining the Intersection of the State and Rural America: A Review Essay
}

\author{
JON LAUCK
}

The Countryside in the Age of the Modern State: Political Histories of Rural America, edited by Catherine McNicol Stock and Robert Johnston. Ithaca: Cornell University Press, 2001. xii, 335 pp. Notes, bibliography, index. $\$ 45.00$ cloth, $\$ 24.95$ paper.

THE HISTORY OF RURAL AMERICA is largely unwritten. The problem has often been lamented, but never corrected. The history of the American state, while it has received more attention than rural America, is also seriously neglected. Current trends in the American academy prevail against these two fields of study. The fine anthology edited by Catherine McNicol Stock and Robert Johnston underscores the critical intersection between state policy and rural America. They recognize that the neglect of state and rural history is linked to the "hegemony of social history" within the history profession and the "increasing strength of a cultural studies whose practitioners often expressed hostility to the political" (6). The problem is compounded, in the words of Wendell Berry, by "modern society's widespread prejudice against country people." ${ }^{\prime 1}$ Nonetheless, Stock and Johnston soldier on. All who take seriously the history and problems of rural America are in their debt.

1. Wendell Berry, "The Prejudice against Country People," The Progressive (April 2002), 22.

THE ANNALS OF IOWA 62 (Spring 2003). (C) The State Historical Society of Iowa, 2003. 
Given its prominent, albeit paradoxical, place in American history, the minimal attention to the intersection of the state and rural life is a curious matter. The role and size of the national state was the central issue in early American politics-to the Federalists, a powerful central state was a matter of national survival. But in 1800 Jefferson and his farmer-supporters sought a retrenchment of federal power, which they saw as a tool wealthy merchants used to undermine the agrarian composition and republican integrity of the new nation. One of Jefferson's highest priorities was repealing the federal whiskey tax, which he deemed anti-farmer and anti-frontier. As it turned out, a century hence, farmers called on the state to protect the remaining Jeffersonian elements of the republic from the wrenching social and economic changes wrought by industrialism. As Ellis Hawley, one of the preeminent historians of the American state, has noted, reformers began to use Hamiltonian means to pursue Jeffersonian ends. ${ }^{2}$

But to conclude that Federalist-style state-building was always enlisted in the cause of Jefferson's vision would not be entirely accurate. Some state actors promoted agrarian "reforms" at odds with the Jeffersonian tradition. Deborah Fitzgerald, in her essay, "Accounting for Change," makes this abundantly clear. Contrary to the agrarian idylls that Jefferson imagined, state-sponsored experts in the 1920s "persuaded" farmers to "industrialize their farms" (190). Fitzgerald's argument is important for all of social science since it counters the assumption that farmers, when expanding and mechanizing their farms, were simply making an economically "rational" decision. In the 1910s and 1920s, Fitzgerald notes, "agriculture was dominated by the agricultural economists and engineers" who convinced farmers of the importance of income and expense accounting, the efficiencies gained through orderly organization of one's farm buildings, the benefits of owning a tractor, and the importance of using these methods and tools to expand and create "corporate farms" modeled on the large-scale industrial firms of the 1920s (193). Fitzgerald explains that "corporate farm enthu-

2. Ellis W. Hawley, The New Deal and the Problem of Monopoly: A Study in Economic Ambivalence (Princeton, NJ, 1966), 8. 
siasts railed against farmers' irrational, romantic, nearly childlike absorption in farm life itself, their interest in the 'way of life' aspects of farming rather than the production aspects, and against farmers' highly irregular work habits" (202). In their attempt to rationalize and modernize American agriculture, economists and engineers even used their experience in the Soviet Union, where many of them had coordinated the communist attempt to marshal large-scale technology for use on new collective farms. "While a tremendous amount of wheat was raised," Fitzgerald notes, "it was virtually all confiscated by the government, contributing to the infamous rural famine that killed millions of people" (210). Stalin was no Jeffersonian. During the depth of the Cold War, the American government would, paradoxically, advise countries attempting to squelch communist rebellions to adopt "land reform" programs to decentralize land-holding at the same time that American agricultural production was rapidly consolidating. ${ }^{3}$

Fitzgerald's greatest contribution is to widen our conception of politics. As she notes, government officials' embrace of "modern" engineering and economics was much more important than some of the pro-farmer regulatory legislation of the 1920s. "The stirring of a revolution in American agricultural practice, shaped extensively by technocratic and scientific approaches created and endorsed by the state, was ultimately more profoundly political than most of the legislation passed in the name of farmers in that decade" (211). Fitzgerald employs James Scott's "high modernist" idea, which criticizes professionals and experts for their arrogant program of "modernizing" all aspects of life at the expense of older traditions. Scott, who also penned the introduction to this anthology, has explained the growing faith in science, rational planning, and progress in the nineteenth century-"high modernism" - which inspired utopian, statesponsored efforts in the twentieth century to modernize the backward, provincial vestiges of Jeffersonianism. Scott's paradigmatic example is the Soviet Union. "Between early 1930 and 1934 , the Soviet state waged a virtual war in the countryside.

3. Jon Lauck, "The Corporate Farming Debate in the Post-World War II Midwest," Great Plains Quarterly 18 (1998), 145. 
Realizing that he could not depend on the rural Soviets to 'liquidate the kulaks' and collectivize, Stalin dispatched twenty-five thousand battle-tested, urban Communists and proletarians with full powers to requisition grain, arrest resistors, and collectivize." ${ }^{\prime 4}$

Jess Gilbert, on the other hand, takes note of intellectuals who attempted to steer the state in a different direction, one more compatible with Jefferson's vision. Gilbert's reformers are not the imperious "high modernists" that Fitzgerald finds. They were, instead, democratic (and largely Democratic) Jeffersonians, and all "Midwestern family farm boys" (217). Their youth on midwestern family farms imprinted upon them the traditional Jeffersonian ideal-" "an ingrained one-class view of society, civic republicanism, and a reforming Protestant spirit" and they set out to use the growing power of the state to protect that tradition (217). They went to midwestern agricultural colleges and studied under John R. Commons and Thorstein Veblen and, as a result, were prepared to resist and intelligently criticize the diktats of the "free market," which was scrambling the social and economic structures of the Jeffersonian Midwest they held dear. Although they were intellectuals and state planners, they did not fall prey to the arrogant "high modernism" described by Scott and Fitzgerald. They were, in Gilbert's view, "low modernists" at best, capable of using new powers to promote an older notion of a just political economy.

Gilbert's focus on these reformers underscores the unfortunate turn in academic history and the overall degradation of academe, which undermines the possibility of what Leon Fink calls a "grand plan for a dialogue between intellectuals and a mass audience" (236). It highlights the chasm between the obsessions of today's rootless, globe-trotting intellectuals and the midwestern, agrarian "organic intellectuals" of an earlier day, who were "linked closely with the class from which they emerge[d] and which they serve[d]," who "came from and never forgot-indeed they worked primarily for-the interest of midsize propertied family farmers" (237). Agricultural professors of those years, according to the agricultural economist

4. James C. Scott, Seeing Like a State: How Certain Schemes to Improve the Human Condition Have Failed (New Haven, CT, 1998), 202. 
M. L. Wilson, felt "a sort of moral responsibility for keeping in close touch with the farmers of their state" (222). Until some of the postmodern absurdities of the present academy can be transcended, it will be impossible, as Gilbert hopes, to "reclaim and reinvent that [organic intellectual] tradition in the service of democracy, agrarian and otherwise" (239).

Katherine Jellison's essay, "An 'Enviable Tradition' of Patriarchy," explores a project launched by one of the New Deal agrarians studied by Gilbert. Carl Taylor's Division of Farm Population and Rural Welfare within the Bureau of Agricultural Economics in the U.S. Department of Agriculture specifically explored alternatives to commercial, "industrial agriculture." Taylor's researchers noted that Amish farmers in Pennsylvania were better able to manage the chaos of the Great Depression than farmers in Kansas, among other places. They noted, among other things, that Amish farm families required the involvement of women in day-to-day agricultural production. In Kansas, however, more farm families were adopting an "urban, middle-class household model, in which farm men used mechanized equipment to produce a few major cash crops and farm women became full-time homemakers and consumers who used labor-saving domestic appliances within the home" (243). Taylor's office conducted "community stability-instability" studies on contrasting rural areas and concluded, after reviewing several criteria, that the "self-sufficient, highly religious Old Order Amish indeed seemed the very model of community stability, in direct contrast to the cash-dependent, drought-plagued residents of Sublette, Kansas" (245). The studies emphasized the advantages Amish farms enjoyed due to the farm work of women. According to Jellison, the "Taylor group's commitment to small-scale, diversified farming represented a minority position among federal policymakers" and, as a result, like the broader work of Gilbert's agrarian intellectuals, their efforts were ultimately undermined by Congress (252). What Jellison finds compelling is the Taylor group's "promotion of a brand of patriarchy more in line with USDA standards of the 1800s than of the twentieth century" (256). The USDA, she argues, "was not a monolith" (256). She uses a micro-story, with a forced emphasis on trendy issues of patriarchy, to prove Gilbert's larger point 
about an alternative agrarian tradition among federal policy makers.

The editors round out the section titled "Constructing the Modern State," which includes the essays by Fitzgerald, Gilbert, and Jellison, with Robert Weise's essay, "Remaking Red Bird," which describes a rather bizarre effort during President Johnson's War on Poverty to modernize "backward" Kentuckians in the Appalachian hollows. It was an attempt to relocate 115 families into a "New Town," a "planned, modern urban area that would provide an alluring alternative to rural isolation and poverty" (260). Weise rightly sees the "War on Poverty" as a "War on Provincialism," which betrays the belief of postwar liberals that "relocating and urbanizing rural people would place them in touch with the blessings of modern living and would reaffirm in the minds of middle-class Americans that the country was and ought to be urban and cosmopolitan rather than rural, isolated, and provincial" (261). Needless to say, local residents did not take kindly to the pity from uppity reformers. One local woman declared, "us hillbillies, we don't bother nobody. We go out of our way to help people. We don't want nobody pushing us around. Now, that's the code of the hills" (270). Due to local resistance, the plan for a "New Town" fell apart. Planners, according to Weise, were too concerned about integration and relocation plans and too hostile to local tradition. In the end, he concludes, such "high modernism," as Scott would deem it, "gave ammunition to conservative groups that see only a limited role for the state in American life" (278).

Oddly, the anthology ignores the only macro-level program affecting millions of farmers, the federal farm subsidy program. Instead, the essays focus primarily on micro or regional programs. Benjamin Johnson analyzes how opponents of the Dawes Act, which allowed Indians to alienate reservation property, embraced agrarian and Populist ideology as a rationale for opposing such legislation, which they viewed as driven by avaricious railroad and land companies. Johanna Schoen examines state-based efforts to promote birth control in North Carolina. And Cindy Hahamovitch reviews state regulation of Jamaican farm-worker immigration. Other essays review the origins of national conservation policy by examining Yellowstone Park's 
early conservation efforts, the role of African Americans in Texas Progressivism, and the often-told story of the Bracero farm-worker program.

Despite the editors' decision to minimize attention to the general subject and focus on the margins, the shortage of scholarly work certainly extends to what the editors call the "standard agrarian icon, the white small-propertied farmer" (9) in the "Jeffersonian Midwest" (5). Scholars of rural history and politics are in the editors' debt for adding to our storehouse of knowledge. As the editors would no doubt agree, much remains to be learned. 
Copyright of Annals of Iowa is the property of State of Iowa, by \& through the State Historical Society of Iowa and its content may not be copied or emailed to multiple sites or posted to a listserv without the copyright holder's express written permission. However, users may print, download, or email articles for individual use. 